ISSN1027-5495. Functional Materials, 23, No.2 (2016), p. 224-229

doi:http://dx.doi.org/10.15407/fm23.02.224

(C) 2016 - STC “Institute for Single Crystals"

\title{
Research on stress intensity factors of elliptical hole in infinite body
}

\author{
Baoliang Liu ${ }^{1,2 *}$ Guangping Zou ${ }^{1}$ \\ ${ }^{1}$ College of Aerospace and Civil Engineering, Harbin Engineering \\ University, Harbin, 150001, P.R.China \\ ${ }^{2}$ Science college, Heilongjiang Institute of Science and Technology, Harbin \\ 150022, P.R.China \\ ${ }^{3}$ Research Laboratory on Composite Materials, Harbin Institute of \\ Technology, Harbin, 150001, P.R.China
}

\section{Received November 7, 2015}

\begin{abstract}
This paper deals with such a kind of surface crack problem with an approximately same depth by using the hybrid displacement discontinuity method (a boundary element method) proposed recently by the author. Based on surface rectangular crack in infinite solid in tension and a hybrid displacement discontinuity method, a numerical approach is presented. By changing geometry parameters of elliptical hole, the effect of geometry parameters of the elliptical hole in infinite body in tension on the SIFs is revealed in detail. It is illustrated that the boundary element method is simple, yet accurate for calculating the SIFs of complex crack problems in finite plate.
\end{abstract} hole

Keywords: Stress intensity factors, hybrid displacement discontinuity method, elliptical

В статье рассматривается проблемы поверхностных трещин приблизительно одинаковой глубины с использованием гибридного метода разрывных смещений (метод граничных элементов)ю. Основываясь на поверхности прямоугольной трешины в сплошном бесконечном теле, представлен численный подход гибридных разрывных смещений к напряжениям. Методом гибридных разрывных смещений детально изучено влияние изменения геометрических параметров эллиптической трещины в бесконечном теле на коэфффициенты интенсивности напряжений. Это иллюстрирует, что метод граничных элементов является простым, и подходящим для их расчета для сложных проблем трещин в конечной пластине.

Дослідження факторів інтенсивності напруг еліптичного отвору у нескінченних тілах. Баолианг Ліу, Гуангпинг Зоу

У статті розглядаються проблеми поверхневих тріщин приблизно однакової глибини 3 використанням гібридного методу розривних зсувів (метод граничних елементів), запропонований недавно автором. Ірунтуючись на поверхні прямокутної тріщини в суцільному нескінченному тілі, представлено чисельний підхід гібридних розривних зсувів до напруг. Методом гібридних розривних зсувів детально вивчений вплив зміни геометричних параметрів еліптичної тріщини в нескінченному тілі на коефіцієнти інтенсивності напруг (КИН). Це ілюструє, що метод граничних елементів є простим, та підходить для розрахунку КИН для складних проблем тріщин у кінцевій пластині. 


\section{Introduction}

In aircraft structures, fatigue failures usually occur from the initiation and propagation of cracks from notches or defects in the material that are either embedded, on the surface, or at a corner. These cracks propagate with elliptic or near-elliptic crack fronts. The stress-intensity factor concept has been used to correlate fatigue crack-growth rates and to determine fracture properties of engineering materials. For plane elastic continua containing cracks, the stress-intensity factors usually have been obtained from they are constant across the thickness [1-2]. For fracture specimens of finite thickness, however, the stress-intensity factors vary along the crack front.

For three-dimensional elastic continua with cracks, the stress field near the crack front is obtained by the solution fo the Navier's equations of equilibrium subjected to appropriate boundary conditions [3]. For fracture specimens of finite thickness with through-the-thickness cracks, some attempts have been made to obtain the stress distribution close to the crack front, but the solutions have been found to be intractable in closed form [4-5]. This paper deals with such a kind of surface crack problem with an approximately same depth. As an example, shown in Fig. 1 is a schematic of a pair of cracks emanating from a surface square defect in infinite body in tension, which is also called a surface defect crack problem. Based on the previous investigations [6-9] on internal rectangular crack and surface rectangular crack in infinite solid in tension and a hybrid displacement discontinuity method (a boundary element method) proposed recently by Ref. [10], a numerical approach for the liked-plane crack problem in hand is presented.

In addition, here, it is pointed out that finite element simulations [11-12] when used to analyze crack problems have to face largely computational problems connected with the discretization of the continuum into finite elements, particularly when some cracks propagate, thus changing the interior boundaries of the solids. Recently, it was found from the previous investigation [13-17] that the hybrid displacement discontinuity method has huge robustness in analyzing complex plane elastic crack problems, including a multiple-hole-crack interaction problem, a multiple crack interaction problem.

For finite bodies, all solutions have required approximate analytical methods. For a semicircular surface crack in a semi-infinite solid

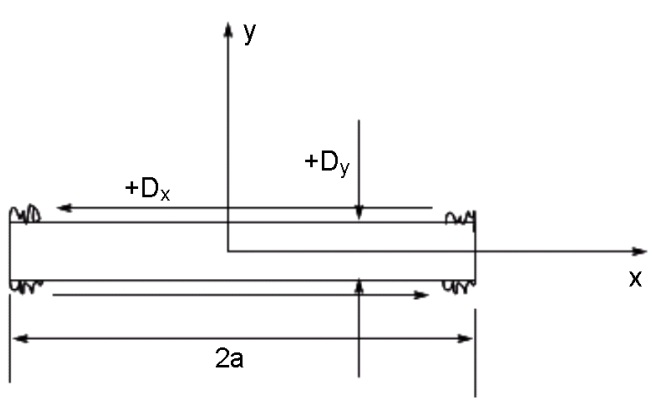

F'ig.1 Schematic of constant displacement discontinuity components $D_{x}$ and $D_{y}$

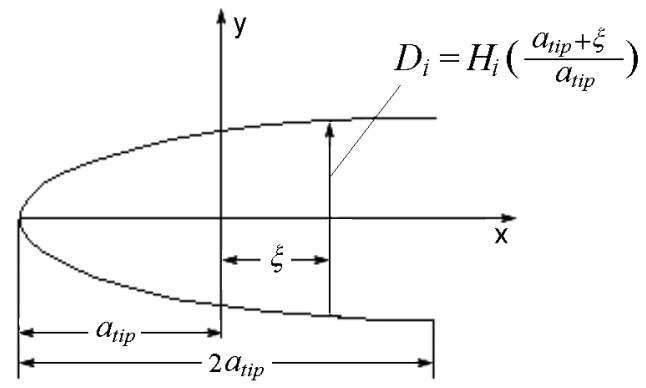

Fig.2 Schematic of the left crack tip displacement discontinuity element

and a semi-elliptical surface crack in a plate of finite thickness, Smith, Emery, and Kobayashi [18], and Kobayashi [19], respectively, used the alternating method to obtain stress intensity factors along the crack front.

\section{Brief description of the hybrid displacement discontinuity method}

In this section, the hybrid displacement discontinuity method presented by Ref. [13] is described briefly. It consists of the constant displacement discontinuity element presented by Crouch and Starfield [20] and the crack-tip displacement discontinuity elements.

\subsection{Constant Displacement Discontinu- ity Method}

The displacement discontinuity $D_{i}$ is defined as the difference in displacement between the two sides of the segment [18] (see Fig.1):

$$
\begin{aligned}
& D_{x}=u_{x}\left(x, 0_{-}\right)-u_{x}\left(x, 0_{+}\right), \\
& D_{y}=u_{y}\left(x, 0_{-}\right)-u_{y}\left(x, 0_{+}\right) .
\end{aligned}
$$

The solution to the subject problem is given by Crouch and Starfield [28]. The displacements and stresses can be written as

$$
\begin{aligned}
u_{x}= & D_{x}\left[2(1-v) F_{3}(x, y)-y F_{5}(x, y)\right]+ \\
& +D_{y}\left[-(1-2 v) F_{2}(x, y)-y F_{4}(x, y)\right], \\
u_{y}= & D_{x}\left[(1-2 v) F_{2}(x, y)-y F_{4}(x, y)\right]+ \\
& +D_{y}\left[2(1-v) F_{3}(x, y)-y F_{5}(x, y)\right],
\end{aligned}
$$


and

$$
\begin{aligned}
\sigma_{x x}= & 2 G D_{x}\left[2 F_{4}(x, y)+y F_{6}(x, y)\right]+ \\
& +2 G D_{y}\left[-F_{5}(x, y)+y F_{7}(x, y)\right], \\
\sigma_{y y}= & 2 G D_{x}\left[-y F_{6}(x, y)\right]+ \\
& +2 G D_{y}\left[-F_{5}(x, y)-y F_{7}(x, y)\right], \\
\sigma_{x y}= & 2 G D_{x}\left[-F_{5}(x, y)+y F_{7}(x, y)\right]+ \\
& +2 G D_{y}\left[-y F_{6}(x, y)\right] .
\end{aligned}
$$

Function $f(x, y)$ in these equations can be written as:

$$
\begin{aligned}
& f(x, y)=\frac{-1}{4 \pi(1-v)}\left[y\left(\arctan \frac{y}{x-a}-\arctan \frac{y}{x+a}\right)-\right. \\
& \left.-(x-a) \ln \sqrt{\left[(x-a)^{2}+y^{2}\right]}+(x+a) \ln \sqrt{\left[(x-a)^{2}+y^{2}\right]}\right] \\
& f(x, y)=\frac{-1}{4 \pi(1-v)}\left[y\left(\arctan \frac{y}{x-a}-\arctan \frac{y}{x+a}\right)-\right. \\
& \left.-(x-a) \ln \sqrt{\left[(x-a)^{2}+y^{2}\right]}+(x+a) \ln \sqrt{\left[(x-a)^{2}+y^{2}\right]}\right]
\end{aligned}
$$

$G$ and $v$ in these equations are shear modulus and Poisson's ratio, respectively. Functions $F_{2}$ through $F_{7}$ are described in Ref. [28]. Eqs (2) and (3) are used by Crouch and Starfield[32] to set up a constant displacement discontinuity boundary element method.

\section{2 Crack-tip displacement disconti- nuity elements}

By using the Eqs (2) and (3), recently, Yan [10] presented crack-tip displacement discontinuity elements, which can be classified as the left and the right crack-tip displacement discontinuity elements to deal with crack problems in general plane elasticity. The following gives basic formulas of the left crack-tip displacement discontinuity element.

For the left crack-tip displacement discontinuity element (see Fig.2), its displacement discontinuity functions are chosen as

$$
D_{x}=H_{s}\left(\frac{a_{t i p}+\xi}{a_{t i p}}\right)^{\frac{1}{2}}, \quad D_{y}=H_{n}\left(\frac{a_{t i p}+\xi}{a_{t i p}}\right)^{\frac{1}{2}} .
$$

where $H_{s}$ and $H_{n}$ are the tangential and normal displacement discontinuity quantities at the center of the element, respectively, $a_{\text {tip }}$ is a half length of crack-tip element. Here, it is noted that the element has the same unknowns as the two-dimensional constant displacement discontinuity element. But it can be seen that the displacement discontinuity functions defined in (5) can model the displacement fields around the crack tip. The stress field determined by the displacement discontinuity functions (5) possesses $r^{-1 / 2}$ singularity around the crack tip.
Based on the Eqs (2) and (3), the displacements and stresses at a point $(x, y)$ due to the left crack-tip displacement discontinuity element can be obtained,

$$
\begin{aligned}
u_{x}= & H_{s}\left[2(1-v) B_{3}(x, y)-y B_{5}(x, y)\right]+ \\
& +H_{n}\left[-(1-2 v) B_{2}(x, y)-y B_{4}(x, y)\right], \\
u_{y}= & H_{s}\left[(1-2 v) B_{2}(x, y)-y B_{4}(x, y)\right]+ \\
& +H_{n}\left[2(1-v) B_{3}(x, y)-y B_{5}(x, y)\right],
\end{aligned}
$$

and

$$
\begin{aligned}
\sigma_{x x}= & 2 G H_{s}\left[2 B_{4}(x, y)+y B_{6}(x, y)\right]+ \\
& +2 G H_{n}\left[-B_{5}(x, y)+y B_{7}(x, y)\right], \\
\sigma_{y y}= & 2 G H_{s}\left[-y B_{6}(x, y)\right]+2 G H_{n}\left[-B_{5}(x, y)-\right. \\
& \left.-y B_{7}(x, y)\right], \\
\sigma_{x y}= & 2 G H_{s}\left[-B_{5}(x, y)+y B_{7}(x, y)\right]+ \\
& +2 G H_{n}\left[-y B_{6}(x, y)\right],
\end{aligned}
$$

where functions $B_{2}$ through $B_{7}$ are described in Ref. [23].

\subsection{Computational formulas of the} stress intensity factors

The objective of many analyses of linear elastic crack problems is to obtain the SIFs $K_{\mathrm{I}}$ and $K_{\mathrm{II}}$. Based on the displacement field around the crack tip, the following formulas exist

$$
K_{\mathrm{I}}=-\frac{\sqrt{2 \pi} G H_{n}}{4(1-v) \sqrt{a_{t i p}}}, K_{\mathrm{II}}=-\frac{\sqrt{2 \pi} G H_{s}}{4(1-v) \sqrt{a_{t i p}}} .
$$

\section{Numerical approach}

A surface crack is usually treated with as a three-dimensional problem to analyze, which undoubtedly is very complex. This paper is concerned with such a kind of surface crack with an approximately same depth, which is called a liked-plane crack. By using the solution of the liked-plane crack problem shown in Fig.3, in

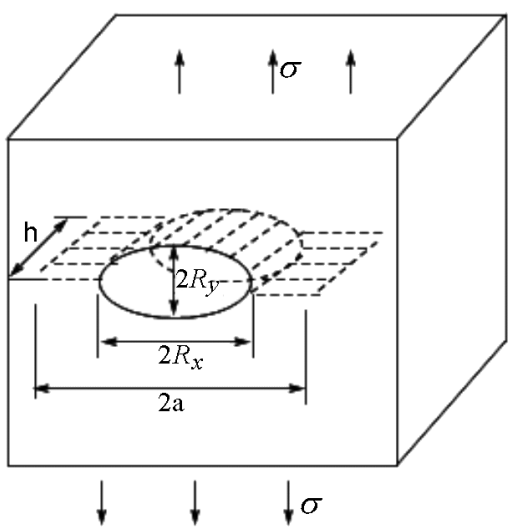

Fig.3 Schematic of a fair of cracks emanating from a surface square hole in infinite body in tension 


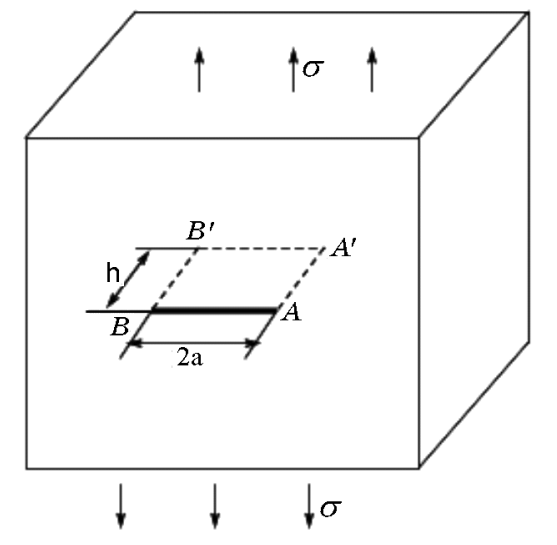

a)

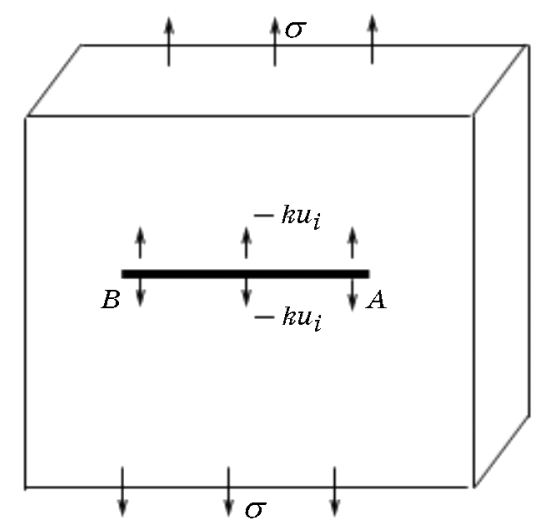

b)

Fig.4 Schematic of a liked-plane crack: (a) a surface crack with a rectangular section, (b) a plane cracked body with a force $-k u_{i}$ acted on the crack surface

this section, we try to present a numerical approach to treat with a liked-plane crack problem.

We imagine that a plane elasticity crack body is separated from the three-dimensional surface crack body (Fig.3): it has the same form crack as that of the three-dimensional surface crack body and is subjected to the same form load as that of the three-dimensional surface crack body. Further it is assumed that there is a force $-k u_{i}$ acted on crack surface shown in Fig. 4 (b), where the spring constant $k$ will be identified later.

Now consider the formulation of the plane elastic crack problem shown in Fig.4 (b). When three is not the force $-k u_{i}$ acted on crack surface shown in Fig. 4 (b), boundary element equations can be written as [10]

$$
\begin{aligned}
& \sum_{j=1}^{N} A^{i j}{ }_{s s} D^{j}{ }_{s}+\sum_{j=1}^{N} A^{i j}{ }_{s n} D^{j}{ }_{n}=\sigma_{s}^{i}, \\
& \sum_{j=1}^{N} A^{i j}{ }_{n s} D^{j}{ }_{s}+\sum_{j=1}^{N} A^{i j}{ }_{n n} D^{j}{ }_{n}=\sigma_{n}^{i},
\end{aligned}
$$

where $N$ is the number of total boundary elements, $A^{i j}{ }_{n n}$,etc are the influence coefficients, which are how to be calculated, to constant displacement discontinuity elements and cracktip elements, are described respectively in Refs $[32,10]$, and $D_{s}^{j}$ and $D_{n}^{j}$ are displacement discontinuities. When considering the acted force $-k u_{\text {i }}$, see Fig.4(b), boundary element equations of the plane elastic crack problem shown in Fig.4(b) can be represented as

$$
\begin{gathered}
\sum_{j=1}^{N} A_{s s}^{i j} D_{s}^{j}+\sum_{j=1}^{N} A_{s n}^{i j} D_{n}^{j}=\sigma_{s}^{i}+k u^{i}{ }_{s} \\
\sum_{j=1}^{N} A^{i j}{ }_{n s} D^{j}{ }_{s}+\sum_{j=1}^{N} A^{i j}{ }_{n n} D_{n}^{j}=\sigma_{n}^{i}+k u_{n}^{i}, \\
(j=1,2, \ldots, N)
\end{gathered}
$$

By substituting the displacement discontinuity $D$ for the displacement $u_{\mathrm{i}}$ in Eqs (10), Eqs (10) can be written as

$$
\begin{gathered}
\sum_{j=1}^{N} A_{s s}^{i j} D_{s}^{j}+\sum_{j=1}^{N} A_{s n}^{i j} D_{n}^{j}=\sigma_{s}^{i}-0.5 k D_{s}^{i}, \\
\sum_{j=1}^{N} A_{n s}^{i j} D_{s}^{j}+\sum_{j=1}^{N} A_{n n}^{i j} D_{n}^{j}=\sigma_{n}^{i}-0.5 k D_{n}^{i}, \\
(j=1,2, \ldots, N)
\end{gathered}
$$

Further Eqs (11) can be rewritten as

$$
\begin{gathered}
\left(A^{i i}{ }_{s s}+0.5 k\right) D_{s}^{i}+\sum_{j=1, j \neq i}^{N} A_{s s}^{i j} D_{s}^{j}+\sum_{j=1}^{N} A^{i j}{ }_{s n} D_{n}^{j}=\sigma_{s}^{i}, \\
\sum_{j=1}^{N} A_{n s}^{i j} D_{s}^{j}+\sum_{j=1, j \neq i}^{N} A_{n n}^{i j} D_{n}^{j}+\left(A^{i i}{ }_{n n}+0.5 k\right) D_{n}^{i}=\sigma_{n}^{i}, \\
(j=1,2, \ldots, N)
\end{gathered}
$$

\section{Numerical results and discussions}

Shown in Fig.3 is a fair of cracks emanating from a surface elliptical hole with a depth $h$ subjected to uniform stress $\sigma$ at infinity. For convenience, we first treat with the case $R_{y}=R_{x}=R$, i.e., a surface circular hole crack problem. For this crack problem, the symmetry condition can be used. The following geometry parameters are considered

$a / R=1.005,1.01,1.02,1.04,1.06,1.08,1.10$,

$1.15,1.20,1.50,2.0,5.0,10.0$

$$
h / a=1.0,1.1,1.2,1.3,1.4,1.6,1.8,2.0
$$

The calculated normalized SIFs at the crack tip A listed in Fig.5 can be used to reveal the effect of geometry parameters, $a / R$ and $h / a$, on the normalized SIFs. Fig.5 shows variation of the normalized SIFs at the crack tip A with h/a for three cases: $h / a=1.0,1.4$ and 2.0.

In order to well reveal the effect of a surface hole the SIFs of $\operatorname{crack}(\mathrm{s})$ emanating from the surface hole, here, the SIFs of the surface hole crack problem and the surface rectangu- 


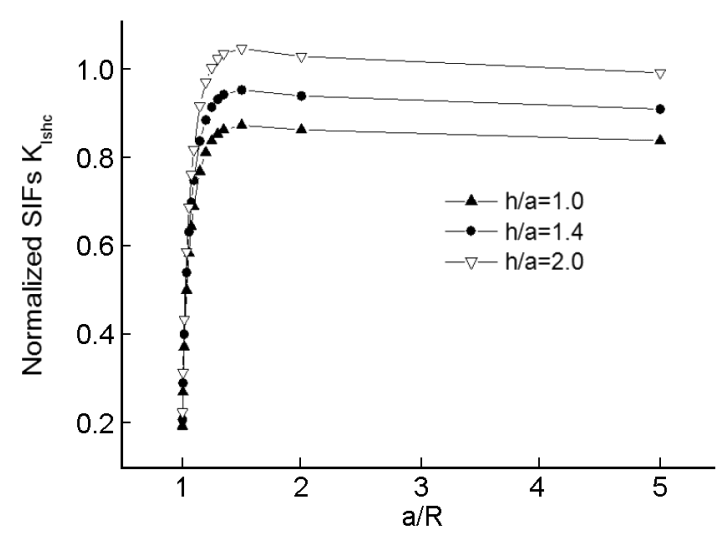

Fig.5 Variation of the normalized SIFs at the crack tip $A$ with $a / R$ and $h / a$

lar crack (length=2a, depth=h) are denoted by $K_{I s c h c}(a / R, h / a)$ and $K_{I s r c}(h / a)$, respectively. Their ratio is denoted by $F_{\text {Ischc }}(a / R, h / a)$, i.e.,

$$
\begin{aligned}
& F_{\text {Ischc }}(a / R, h / a)= \\
& =K_{\text {Ischc }}(a / R, h / a) / K_{\text {Isrc }}(h / a),
\end{aligned}
$$

which is also called a normalized SIFs. The normalized SIFs corresponding to $h / a=1.3$ are shown in Fig.6.

For convenience to discuss, we introduce a parameter, $a_{r}=a / R$. From Table5 and Fig.6, it can be seen that

(a) With increase of $a_{r}$ (i.e., with decrease of the surface circular hole radius $R), F_{\text {Ischc }}$ fast increases monotonously, and as $a_{r}$ reaches a certain value $a_{r c}, F_{I s c h c}=1$, i.e., $F_{I s c h c}$ equals $K_{\text {Isrc }}$. Here, $a_{r c}$ is between 1.20 and 1.25.

(b) With continuous increase of $a_{r}, F_{\text {Ischc }}$ begins to increase slowly and reaches its maximum $F_{\text {Ischcm }}$ at some value $a_{r m}$. Here, $a_{r m}$ and $F_{\text {Ishcm }}$ are about 1.50 and 1.06 , respectively.

(c) Continuous increase of $a_{r}$ leads to $F_{\text {Ischc }}$ to begin to decrease slowly and $F_{\text {Ischc }}$ almost equals 1 (i.e., $F_{I s c h c}$ almost equals $K_{I s r c}$ ) when $a_{r}$ is large enough.

After introducing the dimensionless parameters $a_{r c}, a_{r m}$ and $F_{I s c h c m}$, it is found that:

(1) As $a_{r}<a_{r c}$, the surface circular hole has a shielding effect on the cracks emanating from the surface hole. And the closer the size of the surface circular hole is to that of the surface crack, the stronger the shielding effect is.

(2) As $a_{r}>a_{r c}$, the surface circular hole has an amplifying effect on the SIFs of the surface crack and the amplifying effect is the most obvious at $a_{r}=a_{r m}$.

(3) As $a_{r}$ is large enough, i.e., the size of the surface circular hole is small enough relative to that of the surface crack, the effect of the surface circular hole on the SIFs of the surface crack is almost neglected.

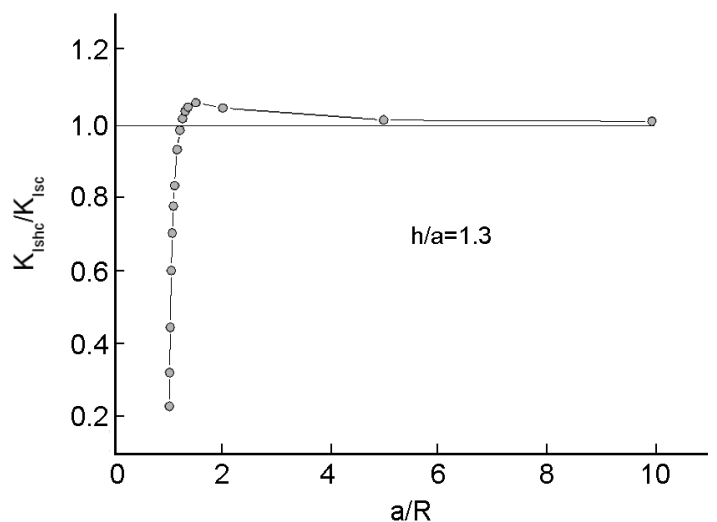

Fig.6 Normalized SIFs $F_{\text {m }}$ of a fair of cracks emanating from a surface square hole $(h / a=1.3)$

\section{Conclusions}

A numerical approach for a liked-plane crack problem was presented in this paper. The numerical approach is simple, yet accurate for calculating the SIFs of a liked-plane crack. The SIFs of a pair of cracks emanating from a surface elliptical hole in infinite body in tension are analyzed in detail. It is found that there are the dimensionless parameters $a_{r c}, a_{r m}$ and $F_{\text {Ishcm }}$, which can be used to reveal the effect of a surface elliptical hole on cracks emanating from the surface hole.

\section{Acknowledgement}

Special thanks are due to the National Natural Science Foundation of China (No. 11572113 and No. 51478168), the talent project of Harbin City (2015RAQXJ005) and Young talent project of Heilongjiang University of Science and Technology for supporting the present work.

\section{References}

1. Paul C. Paris, George C. Sih, Spec. Tech. Publ. 381, 30, 1987.

2. M. L. Williams, J. Appl. Mech., 24, 109,1957.

3. M. K. Kassir, G. C. Sih, J. Appl. Mech., 88, 601, 1966.

4. R. J. Hartranft, G. C. Sih, J. Math. Mech., 19, 123, 1969.

5. G. C. Sih, Int. J. Fract. Mech.,7, 39, 1971.

6. Y. Murakami, M. Isida, Trans. Japan Soc. Mech. Engrs., 51, 1050, 1985.

7. Y. Murakami, S. Nemat-Nasser, Eng. Frat. Mech., 17, 193, 1983.

8. T. Yoshida, Kyushu Univer., Fukuoka, Japan, 1984.

9. K.K. Kassir, ASME J. Appl Mech., 48, 309, 1981.

10. Yan, X., ASME J. Appl. Mech., 72, 330, 2005. 
11. P.G. Charambides, R.M. McMeeking, Mech.Mater., 6, 71, 1987.

12. X. Huang, B.L. Karihaloo, Int J. Solid. Struct., 25, 591,1993.

13. X. Yan, Engin. Failure Analys., 12, 362, 2005.

14. B. Liu, X. Yan, J. Harbin Inst. Techn., 43, 51, 2011.

15. B. Liu, L. Yan, X. Yan, J. Liaon. Techn. Univ., 31, 540, 2012.

16. X. Yan, B. Liu, Z. Hu, Mechanica, 42, 1331, 2010.
17. X. Yan, J. Strain Anal. Engin. Design, 41, 9, 2006.

18. F. W. Smith, A. F. Emery, A. S. Kobayashi, J. Appl. Mechs., 34, 953, 1967.

19. A. S. Kobayashi, ASM, 10731976.

20. S. L. Crouch, A. M.Starfied, "Boundary Element Method in Solid Mechanics, with Application in Rock Mechanics and Geological Mechanics", London, Geore Allon \& Unwin, Bonton, Sydney, 1983. 